\title{
Farklı Dozlarda Sıvı Biyogaz Fermentasyon Atıklarının Ekmeklik Buğday (Triticum aestivum L.) Bitkisinin Verim ve Kalite Üzerine Etkisi
}

\section{Nermin YARAȘIR' (i), Osman EREKUL ${ }^{* 1}$, Ali YiĞIT'}

\author{
${ }^{\prime}$ Aydın Adnan Menderes Üniversitesi Fen Bilimleri Enstitüsü, Aydın \\ ${ }^{2}$ Aydın Adnan Menderes Üniversitesi, Ziraat Fakültesi, Tarla Bitkileri Bölümü, Güney Kampüsü Aydın
}

Öz: Bu çalıșma Adnan Menderes Üniversitesi Ziraat Fakültesi Araștırma ve Uygulama Çiftliğinde 2016/2017 buğday üretim sezonunda tesadüf blokları deneme desenine göre gerçekleștirilmiștir. Denemede materyal olarak Ceyhan 99 çeșidi kullanılmıștır. Çalıșmanın amacı; üç farklı mineral azot gübre dozu $(0,9,18 \mathrm{~kg} / \mathrm{da})$ ve beș farklı sıvı biyogaz atık dozu uygulamasının $(0$, I, 2, 3, 4 ton/da) ve bunların kombinasyonlarının buğday bitkisinde verim ve kalite üzerine etkilerinin belirlenmesi ile sıvı biyogaz atıklarının tarımsal üretimde kullanılma potansiyelinin belirlenmesidir. Çalıșmada; sıvı biyogaz atık uygulaması ile azotlu gübre uygulaması verim ve kalite parametreleri üzerinde istatistiksel anlamda önemli farklılıklar meydana geldiği saptanmıștır. Sıvı biyogaz atık uygulamasının metrekarede $\left(\mathrm{m}^{2}\right)$ bașak sayısı, bașakta tane sayısı, bin tane ağırlı̆ı, hektolitre ağılığı, bayrak yaprak alan miktarı ve tane verimi üzerine önemli etkileri görülmüștür. Kullanılan mineral azot dozları tanede protein oranı dıșında diğer tüm verim ve kalite parametrelerini olumlu etkilemiștir. Denemede genel olarak $3 \mathrm{t} / \mathrm{da}$ sıvı biyogaz atı̆̆ı ile $18 \mathrm{~kg} / \mathrm{da}$ mineral azot dozu kombinasyonunda daha iyi sonuçlar tespit edilmiștir.

Anahtar Kelimeler: buğday, kalite, verim, biyogaz, azot

\section{The Effect of Different Doses of Liquid Biogas Fermentation Wastes on Yield and Quality of Bread Wheat (Triticum aestivum L.)}

Abstract: The study was carried out according to the experimental design of random blocks split plot design in the wheat production season of 2016/17 at Adnan Menderes University Agricultural Faculty Research and Application Farm. Ceyhan 99 variety was used as a wheat variety in the experiment. Purpose of the study is determination of the effects of three different mineral nitrogen fertilizer doses $(0,9,18 \mathrm{~kg} / \mathrm{da})$ and five different liquid biogas waste doses applications ( $0,1,2,3,4$ ton/da) and their combinations on yield and quality in wheat plants besides investigate the effects of the use of liquid biogas waste in agricultural production on soil fertility.

When the results are summarized bread wheat yield and quality parameters are affected by liquid biogas waste and mineral nitrogen fertilizer applications and statistically differences were obtained between applications. Number of spikes per square meter, thousand grain weight, test weight, flag leaf area and grain yield parameters are affected statistically significant by liquid biogas waste applications. The mineral nitrogen doses positively affected all other yield and quality parameters except protein ratio. Better results were usually obtained in the experiment from 3 ton/da liquid biogas waste dose and $18 \mathrm{~kg} / \mathrm{da}$ mineral nitrogen dose combination.

Keywords: wheat, quality, yield, biogas, nitrogen

\section{GiRiș}

Dünya'da ve ülkemizde hızla artan insan ve hayvan varlı̆ı̆ının beslenme ihtiyacını karșılama sorunu, içerisinde bulunduğumuz dönemde tahılların üretimine ayrı bir önem kazandırmaktadır (Anonim, 20I2). Bu anlamda beslenmesi buğdaya dayalı ülkelerin buğday yönünden kendine yeterli olması ve yeterince buğday ürünü bulundurması büyük önem arz etmektedir. Tahıllar yurdumuz insanın beslenmesinde önemli bir yere sahip olması, milyonlarca üreticinin yıllık gelirini sağlayan önemli kaynak olması ve çok sayıda sanayi kurulușunun ana ham maddelerini olușturması gibi özellikleri de dikkate alındığında, stratejik öneme sahip bitkiler olarak değerlendirilmektedir (Șehirali ve ark., 2000). Buğday 2016 yllı verilerine göre tahıllar içerisinde yaklașık 230 milyon hektar ekim alanı ve $\mathbf{7 4 0}$ milyon tonluk üretimi ile en fazla ekim alanına sahip kültür bitkisi olmuștur. Buğday üretimi açısından mısır ve çeltik bitkilerinden sonra üçüncü sırada bulunmaktadır. Ülkemizde ise buğday ekim alanları son yıllarda azalmıș olup 7.8 milyon hektar alanda 23 milyon tonluk bir üretim bulunmaktadır (FAO, 2016).
Dünya ve ülkemiz nüfusunun artması, artan sıcaklıklar, yağıșlardaki değișiklikler, daha fazla kuraklık tarım üretimi üzerinde olumsuz etkiler yaratarak ve gıda arzı dengesini bozmaktadır. Bu nedenle tarımsal verim, gelișmekte olan ülkelerin çoğunda düșmektedir ve su kaynaklarının ve kalitesinin azalması sonucunda beslenme bozukluklarında da artmalar meydana gelmektedir. Uzmanlar bu değișikliklere ayak uydurmak için dünyanın $\% 60$ ile $\% 100$ arasında daha fazla hububat ve hayvancllık üretimi gerçekleștirmesi gerektiğini tahmin etmektedirler (Koca, 20II). Bitkisel üretimde ürün artıșı için tek seçenek birim alan veriminin yükseltilmesidir (Doğan ve Kendal, 20I2).

Türkiye toprakları organik madde bakımından genellikle fakirdir. Birçok bölgede toprakların organik madde içerikleri \%2 hatta \%l'e düșmüștür (Gümüș ve Șeker, 20l4). Organik gübreleme yetersizliği, monokültür veya sınırlı ekim nöbeti

Sorumlu Yazar: oerekul@adu.edu.tr Bu çalsșma yüksek lisans tezi ürünüdür.

Geliș Tarihi: 25 Mart 2018

Kabul Tarihi: 6 Kasım 2018 
uygulamaları ile anız yakılması gibi ișlemler toprak verimliliğinin azalmasına neden olmuștur (Șeker ve Karakaplan, 1999). Organik madde eksikliğinin giderilmesinde çiftlik gübresi, bitkisel atık, tavuk gübresi, organik yapıdaki sanayi atıkları kullanılmaktadır. Bu atıklar toprağın kimyasal ve biyolojik özelliklerini iyileștirerek bitki ve toprağa besin elementi sağlamakta ve bitkisel üretimde verim ve kaliteyi olumlu etkilemektedir. Organik gübre etkinlikleri toprakta mineral içerikli gübrelerden farklı olarak daha uzun süre devam etmekte, toprak ve ürün verimi üzerine olumlu etkiler olușturmaktadır (Entr ve ark., 1997). Günümüzde yașanan iklimsel kaygılar fosil yakıtların yerini yenilenebilir enerji kaynaklarının almasına yöneltmiștir. Yenilenebilir enerji kaynaklarından biri olan biyogaz, organik kökenli tüm atıklardan elde edilmekte ve çevre dostu bir enerji kaynağı profili çizmektedir (Çevik, 20I6). Türkiye gerek yüzölçümü gerek tarım ülkesi olması nedeniyle büyük oranda biyogaz üretim potansiyeline sahiptir. Ancak biyogaz tesisi bakımından gelișmiș ülkelerin çok gerisinde kalmıștır (Gürel, 20I2). Biyogaz; özellikle organik madde oranı yüksek hayvan, bitki, șehir ve endüstriyel atıklardan elde edilmektedir. Biyogaz üretimi anaerobik bir parçalanma sürecini içermektedir. Bu parçalanma süreci hayvansal ve bitkisel atıkların oksijensiz ortamda sıcak koșullarda metan bakterileri tarafından önce asetik aside ardından metan gazına çevrilmesi ișlemidir (Koca, 2007).

Biyogaz bileșiminde organik maddelerin oranına bağlı olarak yaklașık; \%40-70 metan, \%30-60 karbondioksit, \%0-3 hidrojen sülfür ile çok az oranda azot ve hidrojen bulunur. Biyogaz; ucuz, çevre dostu bir enerji ve gübre kaynağıdır. Biyogaz üretimi sonucunda hayvan gübresinde bulunan yabancı ot tohumları çimlenme özelliğini kaybetmekte ve hayvan gübresinin kokusu büyük ölçüde yok olmaktadır. Hayvan gübrelerinden kaynaklanan insan sağlığını ve yer altı sularını tehdit eden hastalık etmenlerinin etkinliği de büyük oranda yok olmaktadır. Biyogaz, çevreye son derece duyarı bir gübredir. Biyogaz üretiminden sonra atıklar yok olmamakta çok daha değerli bir organik gübre haline dönüșmektedir (Kılıç, 20II).

Bu çalıșmada; farklı dozlarda toprağa yalın olarak uygulanan sıvı formdaki biyogaz ve mineral azot gübre dozları ile bunların kombinasyonlarının ekimle birlikte buğday bitkisinde verim ve kalite üzerine etkileri ile tarımsal üretimde kullanılma olanaklarının araștırıması amaçlanmıștır. Ayrıca yapılan çalıșma ile belirtilen gübre uygulamalarının ve kombinasyonlarının toprak verimliliği üzerine etkileri de araștırılmıștır.

\section{MATERYAL ve YÖNTEM}

Çalıșma Adnan Menderes Üniversitesi Ziraat Fakültesi Araștırma ve Uygulama Çiftliğinde 2016/2017 buğday üretim sezonunda gerçekleștirilmiștir.

2016-2017 buğday yetiștirme dönemine ait Aydın ilinin ortalama sıcaklık ve toplam yağıs, değerleri ile uzun yıllara ait ortalama değerleri verilmiștir (Çizelge I).

İklim verileri incelendiğinde; buğday üretim döneminde ortalama sıcaklık değerlerin Kasım, Aralık ve Ocak aylarında

Çizelge I. Deneme yılına ve uzun yıllara ait ortalama aylık sıcaklık ve toplam aylık yağıș değerleri (Anonim 20I7).

\begin{tabular}{lllll}
\hline & \multicolumn{2}{l}{ Ortalama Sıcaklık $^{\circ} \mathbf{C}$} & \multicolumn{2}{l}{ Toplam Yağıș $(\mathbf{m m})$} \\
\hline Aylar & $\mathbf{2 0 1 6 / 2 0 1 7}$ & $\mathbf{1 9 4 0 / 2 0 1 7}$ & $\mathbf{2 0 1 6 / 2 0 1 7}$ & $\mathbf{1 9 4 0 / 2 0 1 7}$ \\
Kasım & 7.1 & 13.4 & 31.6 & 82.6 \\
Aralık & 8.3 & 9.5 & 11.9 & 122.3 \\
Ocak & 6.5 & 8.2 & 221.5 & 115.1 \\
Șubat & 10.2 & 9.32 & 21.7 & 94.5 \\
Mart & 13.7 & 11.7 & 112.5 & 70.3 \\
Nisan & 17.2 & 15.9 & 46.4 & 48.8 \\
Mayıs & 22.6 & 20.9 & 45.0 & 35.1 \\
Haziran & 26.7 & 25.8 & 16.0 & 13.6
\end{tabular}

uzun yıllara ait ortalama sıcaklık değerlerinin altında kaldığı buna karșın Șubat, Mart, Nisan ve Haziran aylarının ortalama sıcaklık değerleri uzun yıllara ait ortalama sıcaklık değerlerinin üzerinde seyretmiștir. Ekimden sonra ortalama aylık sıcaklık değerlerinin buğdayın büyüme ve gelișmesi için gerekli olan minimum sıcaklık değerlerinin üzerinde kaldığı gözlenmiștir. Yağıș ortalamaları incelendiğinde ise Kasım, Aralık ve Ocak aylarında yağıș miktarlarının uzun yıllar ortalamalarının altında kaldığı buğdayın büyüme ve gelișmesi açısında önemli dönemleri kapsayan Mart ve Mayıs aylarında ise yağıș miktarlarının uzun yıllar ortalamasının üzerinde olduğu görülmektedir. Nisan ayındaki yağıs miktarı ise uzun yıllara ait ortalamaya yakın ölçülmüștür (Çizelge I).

Deneme toprağına ait analiz sonuçları incelendiğinde; deneme toprağının kumlu tınlı bir bünyeye sahip olduğu, organik madde miktarının düșük ve alkali karakterli bir yapıya sahip olduğu söylenebilir. Topraktaki makro besin elementlerine bakıldığında $\mathrm{K}$ miktarının düșük, $\mathrm{Na}$ ve $\mathrm{Ca}$ miktarının orta, $\mathrm{Mg}$ miktarının ise çok yüksek olduğu söylenebilir. Ayrıca toprağın tuzsuz ve kireççe zengin olduğu belirlenmiștir (Değirmenci, 20I7) (Çizelge 2). 
Çizelge 2. Deneme alanına ait toprak analiz sonuçları

\begin{tabular}{|c|c|c|c|c|c|c|c|c|c|c|}
\hline $\begin{array}{l}\text { Toprak } \\
\text { (\%) }\end{array}$ & Tekstürü & $\begin{array}{l}\text { Bünye } \\
\text { Sınıfı }\end{array}$ & pH & $\begin{array}{l}\text { Organik } \\
\text { Madde } \\
(\%)\end{array}$ & $\begin{array}{l}\text { Toplam } \\
\text { Tuz (\% }\end{array}$ & $\begin{array}{l}\text { Kireç } \\
\text { (\%) }\end{array}$ & $\begin{array}{l}\text { K } \\
\text { (ppm) }\end{array}$ & $\begin{array}{l}\text { Ca } \\
\text { (ppm) }\end{array}$ & $\begin{array}{l}\text { Mg } \\
\text { (ppm) }\end{array}$ & $\begin{array}{l}\mathrm{Na} \\
\text { (ppm) }\end{array}$ \\
\hline $\begin{array}{l}\text { Kum } \\
67.4\end{array}$ & $\begin{array}{l}\text { Mil } \\
25.8\end{array}$ & $\begin{array}{l}\text { Kumlu } \\
\text { Tın }\end{array}$ & 8.45 & 1.91 & 0.032 & 7.22 & 135 & 1745 & 575 & 95 \\
\hline
\end{tabular}

Çalıșmada materyal olarak ülkemizde yaygın olarak yetiștirilen kıșa ve kurağa orta dereceli dayanıklı Ceyhan 99 buğday çeșidi kullanılmıștır. Bölgede bulunan entegre bir hayvan çiftliği yanında yer alan ve çiftlik gübresi ile $2.4 \mathrm{MW}$ elektrik enerjisi elde edilen yaklașık 5 bin konutun elektrik ihtiyacını karșılayan bir biyogaz tesisinden temin edilmiștir. Temin edilen organik gübrenin kimyasal özellikleri ise; $\mathrm{pH}$ : 8.0, toplam tuz (\%): 2.16, organik madde (\%): 2.02, toplam azot: $\% 0.3$, toplam fosfor $\left(\% \mathrm{P}_{2} \mathrm{O}_{5}\right): 0.3$, suda çözünebilir potasyum oksit $\left(\% \mathrm{~K}_{2} \mathrm{O}\right)$ : $<0.2$ șeklindedir. Taban gübresi olarak kompoze $\left(13: 25: 5+10\left(\mathrm{SO}_{3}+\mathrm{Zn}\right)\right)$ gübre kullanılmıștır. Üst gübre olarak ise \%46'lık üre gübresinden yararlanılmıștır. Deneme tesadüf blokları bölünmüș parseller deneme desenine göre kurulmuștur. Denemede ana faktör mineral azot dozlarını $(0,9,18 \mathrm{~kg} / \mathrm{da})$, alt faktör ise sıvı biyogaz atık dozlarını (0, I, 2, 3, 4 ton/da) olușturmaktadır. Denemede parseller $6 \mathrm{~m}$ uzunluk ve $1.2 \mathrm{~m}$ genișlik olacak șekilde kurulmuștur ve böylece parsel büyüklükleri $7.2 \mathrm{~m}^{2}$ olmuștur. Ekim $20 \mathrm{~cm}$ sıra arası mesafesinde mibzerle yapılmıștır. Deneme üç tekerrürlü olup toplam 45 parselden meydana gelmiștir. Ekimden hemen önce sıvı biyogaz atık uygulaması yapılmıș (23.I1.2016) ve ardından ekim sıklığı $500 \mathrm{bitki} / \mathrm{m}^{2}$ olacak șekilde buğday ekimi gerçekleșmiștir (24.11.2016). Taban gübrelemesinde $0 \mathrm{~kg} / \mathrm{da}$ azot uygulamaları haricinde dekara $3 \mathrm{~kg} / \mathrm{da}$ saf azot gelecek șekilde gübreleme yapılmıștır. Üst gübreleme ise iki defada yapılmıș ve taban gübresinde verilen $3 \mathrm{~kg} / \mathrm{da}$ azot gübresi dikkate alınarak üst gübrelemeler yapılmıștır. Üst gübrelemelerden birincisi kardeșlenme döneminde (07.02.2017) ve $9 \mathrm{~kg} / \mathrm{da} \mathrm{N}$ uygulanan parsellere $3 \mathrm{~kg} / \mathrm{da}$ azot ve $18 \mathrm{~kg} / \mathrm{da}$ azot uygulanan parsellere de $7.5 \mathrm{~kg} / \mathrm{da}$ saf azot gelecek șekilde üre gübresi verilmiștir. İkinci üst gübrelemede ise $9 \mathrm{~kg} / \mathrm{da}$ azot ve $18 \mathrm{~g} / \mathrm{da}$ azot gübre miktarlarını tamamlamak üzere kalan $3 \mathrm{~kg} / \mathrm{da}$ azot ve $7.5 \mathrm{~kg} / \mathrm{da}$ azot gübre uygulamaları sapa kalkma dönemin sonunda (20.03.2017) gerçekleștirilmiștir.

Çalıșmada; verim ve verim öğeleri olarak metrekarede bașak sayısı (adet $/ \mathrm{m}^{2}$ ), bașakta tane sayısı (adet/bașak), bin tane ağırlığı $(\mathrm{g})$ ve tane verimi $(\mathrm{kg} / \mathrm{da})$ ölçülmüștür. Verim ve verim öğelerine yönelik ölçümlerde hasat döneminde her parselden toplanan bașaklar tanelenerek belirlenmiștir.
Ayrıca buğdayın çiçeklenme döneminde (BBCH 6I-65) yaprak alan miktarları LICOR 3000 C yaprak alan ölçüm cihazı ile her parselden rastgele seçilen bitkilerin bayrak yaprak alanları ölçülmüștür. Kalite özelliklerinden ise her deneme parseline ait hektolitre ağırlığı I/4 litrelik hektolitre aletinde tartılmıș, elde edilen değer 4 ile çarpılarak hesaplanmıștır. Tanede protein oranı ise NIRS yöntemiyle (Near Infrared Reflectance Spectroscopy) Brucker (Germany) cihazında Adnan Menderes Üniversitesi Tarımsal Biyoteknoloji ve Gıda Güvenliği Laboratuvarında (TARBIYOMER) saptanmıștır. Çalıșmanın diğer önemli kalite analizini Toplam Antioksidan Aktivite (\%inhibisyon) ölçümü olușturmuștur. Toplam antioksidan aktivite analizi 5 gram öğütülmüș buğday örneği üzerine $50 \mathrm{ml} \% 80$ 'lik matanol ilave edilerek çalkalayıcıda 30 dakika boyunca azot altında karıștırılmıș, ardından 5000 rpm'da 20 dakika boyunca santrifüj edilmiștir. Elde edilen ekstraksiyonlar tüplere alınmıș ve $+4 \circ \mathrm{C}$ sıcaklıkta analizler için bekletilmișlerdir. $0.1 \mathrm{ml}$ ekstrasyon üzerine $3.9 \mathrm{ml} \mathrm{DPPH}$ serbest radikali ilave edilerek karıștırılmıștır. Hazırlanan $4 \mathrm{ml}$ 'lik çözelti su banyosunda $37{ }^{\circ} \mathrm{C}$ de 30 dakika boyunca bekletilmiștir. Süre sonunda örneklerin spektrofotometrede 517 nm'de absorbans ölçümleri yapılmıștır (Brand Williams ve ark., 1995).

\section{BULGULAR ve TARTIȘMA}

\section{Metrekarede Bașak Sayısı (adet $/ \mathbf{m}^{2}$ )}

Elde edilen metrekarede bașak sayısına ait varyans analiz sonuçları değerlendirildiğinde mineral azot gübrelemesi ve sıvı biyogaz atığı uygulaması ile mineral azot $x$ sıvı biyogaz atığı interaksiyonu istatistiksel olarak 0.0 I düzeyinde önemli bulunmuștur.

Metrekarede bașak sayısına ait ortalama değerler Çizelge 3'te gösterilmiștir. Elde edilen değerler incelendiğinde 281 516 adet $/ \mathrm{m}^{2}$ arasında değișim gösterdiği görülmektedir. En yüksek bașak sayısı $9 \mathrm{~kg} / \mathrm{da}$ mineral azot uygulaması ile 4 t/da sıvı biyogaz atık uygulamasında saptanmıștır. En düșük metrekarede bașak sayısı ise mineral azot ve sıvı biyogaz atığının uygulanmadığı parsellerde gözlenmiștir. Mineral

Çizelge 3. Metrekarede bașak sayısına ait ortalama değerler (adet $\left./ \mathrm{m}^{2}\right)$

\begin{tabular}{lllll}
\hline Azot/Sıvı & $\mathbf{0 ~ k g / d a}$ & $\mathbf{9} \mathbf{~ k g / d a}$ & $\mathbf{I 8 ~} \mathbf{~ k g / d a}$ & Ortalama \\
\hline $0 \mathrm{t} / \mathrm{da}$ & $285.33 \mathrm{ef}$ & $405.33 \mathrm{~cd}$ & $362.66 \mathrm{~b}$ & $35 \mathrm{I} . \mathrm{II} \mathrm{C}$ \\
$\mathrm{I} \mathrm{t/da}$ & $293.33 \mathrm{ef}$ & $394.66 \mathrm{~d}$ & $457.33 \mathrm{bc}$ & $38 \mathrm{I} .77 \mathrm{~B}$ \\
$2 \mathrm{t} / \mathrm{da}$ & $281.33 \mathrm{f}$ & $432.00 \mathrm{bcd}$ & $453.33 \mathrm{ab}$ & $388.88 \mathrm{AB}$ \\
$3 \mathrm{t} / \mathrm{da}$ & $304.00 \mathrm{ef}$ & $463.33 \mathrm{~b}$ & $497.33 \mathrm{ab}$ & $415.55 \mathrm{~A}$ \\
$4 \mathrm{t} / \mathrm{da}$ & $322.00 \mathrm{e}$ & $516.00 \mathrm{a}$ & $387.33 \mathrm{~d}$ & $411.77 \mathrm{~A}$ \\
Ortalama & $299.20 \mathrm{~B}$ & $442.26 \mathrm{~A}$ & $428.00 \mathrm{~A}$ &
\end{tabular}

Lsd Azot: 27.682, Lsd Sivı atık: 28.763, Lsd Azot x Sıvı: 49.819

Azot ve Sıvı atık dozlarına ait genel ortalamalar büyük harf ile gösterilmiștir. 
azot uygulaması metrekarede bașak sayısının önemli oranda artmasına neden olmuștur. Bu artıș özellikle dekara $9 \mathrm{~kg}$ mineral azot uygulamasının yapıldığı parsellerde gözlenmiștir. Mineral azot ile sıvı biyogaz atığının birlikte uygulandığı durumlarda daha yüksek bașak sayılarına ulașıımıștır, ancak sıvı biyogaz atığının etkisi bu parametrede mineral azot uygulamalarına göre daha zayıf olmuștur, ancak genel olarak en iyi sonuçlar mineral azot gübrelemenin 2 veya $3 \mathrm{t} / \mathrm{da}$ sıvı biyogaz atığı ile birlikte verildiği parsellerde ortaya çıktığı gözlenmiștir.

Buğday'da tane verimini etkileyen en önemli faktörlerden birinin kardeș sayısına da bağlı olan metrekaredeki bașak sayısı olduğu bilinmektedir (Baysal, 20I4). Lloveras ve ark. (200I) buğday da yapmış oldukları çalıșmada mineral azotlu gübre uygulamasının bașak sayısında ve bașakta tane sayısında artıș sağladığı fakat tane ağırlığının etkilenmediğini belirtmișlerdir. Yine benzer bir diğer çalıșmada mineral azot uygulamasının buğday da kardeșlenme ve birim alandaki bașak sayısını arttırdığı ancak dane ağırlığııın azalmasına neden olduğu bildirilmiștir (Hay ve Walker, 1989).

\section{Bașakta Tane Sayısı (adet/bașak)}

Bașakta tane sayısına ilișkin varyans analiz sonuçları değerlendirildiğinde mineral azot gübrelemesi ve SIVI biyogaz atık uygulamaları istatistiki açıdan 0.01 seviyesinde önemli bulunurken mineral azot $x$ sıvı biyogaz atığı interaksiyonu ise önemsiz bulunmuștur.

Başakta tane sayısına ait ortalama değerler incelendiğinde 2 ton sıvı biyogaz atık uygulamasının ve 9 ile $18 \mathrm{~kg} / \mathrm{da}$ mineral azot gübre uygulamalarının tane sayısına etkilerinin olumlu yönde olduğu ancak aralarında çok büyük farklar olmadı̆̆ı tespit edilmiștir. En düșük bașakta tane sayısı, mineral azot ve sıvı biyogaz atığının uygulanmadığı parsellerde bulunmuștur. En yüksek tane sayısı ise $9 \mathrm{~kg} / \mathrm{da}$ mineral azotun 3 t/da sıvı biyogaz atığının birlikte uygulanması sonucu ölçülmüștür. Mineral azot bașakta tane sayıların önemli oranda artmasına neden olurken yine aynı șekilde sıvı biyogaz atığı da bașakta tane sayılarının artmasına neden olmuștur. Ancak $9 \mathrm{~kg} / \mathrm{da}$ mineral azot dozu ve $2 \mathrm{t} / \mathrm{da}$ sivı biyogaz atığı uygulamaları bu parametrede en yüksek seviyelerin yakalanması için yeterli olmuștur (Çizelge 4).

Çizelge 4. Bașakta tane sayısına ait ortalama değerler (adet/bașak)

\begin{tabular}{lllll}
\hline Azot/Sıvı & $\mathbf{0 ~} \mathbf{~ g} / \mathbf{d a}$ & $\mathbf{9 ~} \mathbf{~ g g / d a}$ & $\mathbf{1 8} \mathbf{~ k g} / \mathbf{d a}$ & Ortalama \\
\hline $0 \mathrm{t} / \mathrm{da}$ & 20.73 & 33.20 & 29.33 & $27.75 \mathrm{~B}$ \\
$\mathrm{I} / \mathrm{da}$ & 22.86 & 30.40 & 32.93 & $28.04 \mathrm{~B}$ \\
$2 \mathrm{t} / \mathrm{da}$ & 29.00 & 32.06 & 32.40 & $33.04 \mathrm{~A}$ \\
$3 \mathrm{t} / \mathrm{da}$ & 28.06 & 33.60 & 30.86 & $31.53 \mathrm{~A}$ \\
$4 \mathrm{t} / \mathrm{da}$ & 27.93 & 32.46 & 29.33 & $30.93 \mathrm{~A}$ \\
Ortalama & $25.72 \mathrm{~B}$ & $32.34 \mathrm{~A}$ & $32.72 \mathrm{~A}$ & \\
\hline
\end{tabular}

Lsd: Azot: 2.450, Lsd Sıvı atık: 2.486, Lsd Azot x Sıvı: öd

Azot ve Sıvı atık dozlarına ait genel ortalamalar büyük harf ile gösterilmiștir.

Yüksek tane verimi için başakta tane sayısı önemli verim öğelerinden biridir. Kara ve Gül (20I3), organik kaynaklı bazı gübrelerin ekmeklik buğdayda tane verimi, verim öğeleri ve protein oranına etkilerini araștırmak amacıyla yaptıkları bir çalıșmada gübre uygulamalarının ekmeklik buğdayda tane verimi, verim özellikleri ve protein oranı üzerine olan etkilerinin önemli olduğunu ortaya koymușlardır. Organik gübre uygulamaların toprak verimliliğinde sağladıkları avantajlar serin iklim tahılların özellikle çiçeklenme ve tane dolum dönemlerinde ve böylece bașakta tane sayısının olumlu yönde etkilenmesinde önemli etkiler meydana getirmektedir (Asmus ve ark., 1990)

\section{Bayrak Yaprak Alan Miktarı (cm²)}

Bayrak yaprak alan miktarına ait varyans analiz sonuçları incelendiğinde, mineral azot gübreleme dozu istatistiksel açıdan 0.0 I seviyesinde önemli bulunurken, sıvı biyogaz atık uygulaması ve mineral azot ile onların interaksiyonları da istatistiksel açıdan önemli $(p<0.05)$ bulunmuștur.

Bayrak yaprak alan miktarlarına ait ortalama değerler Çizelge 5'te gösterilmiștir. Elde edilen değerler

Çizelge 5. Bayrak yaprak alan miktarına ilișkin ortalama değerler $\left(\mathrm{cm}^{2}\right)$

\begin{tabular}{lllll}
\hline Azot/Sıvı & $\mathbf{0 ~} \mathbf{~ g} / \mathbf{d a}$ & $\mathbf{9} \mathbf{~ k g} / \mathbf{d a}$ & $\mathbf{1 8} \mathbf{~ k g / d a}$ & Ortalama \\
\hline $0 \mathrm{t} / \mathrm{da}$ & $18.83 \mathrm{~g}$ & $20.03 \mathrm{fg}$ & $29.00 \mathrm{bc}$ & $22.62 \mathrm{~B}$ \\
$\mathrm{I} \mathrm{t} / \mathrm{da}$ & $22.16 \mathrm{efg}$ & $23.72 \mathrm{defg}$ & $33.28 \mathrm{ab}$ & $26.39 \mathrm{~A}$ \\
$2 \mathrm{t} / \mathrm{da}$ & $24.75 \mathrm{cde}$ & $24.41 \mathrm{cdef}$ & $35.64 \mathrm{a}$ & $28.93 \mathrm{~A}$ \\
$3 \mathrm{t} / \mathrm{da}$ & $29.24 \mathrm{bc}$ & $28.01 \mathrm{~cd}$ & $26.66 \mathrm{cde}$ & $27.97 \mathrm{~A}$ \\
$4 \mathrm{t} / \mathrm{da}$ & $29.27 \mathrm{bc}$ & $27.86 \mathrm{~cd}$ & $27.68 \mathrm{~cd}$ & $28.27 \mathrm{~A}$ \\
Ortalama & $25.25 \mathrm{~B}$ & $24.8 \mathrm{~B}$ & $30.45 \mathrm{~A}$ & \\
\hline
\end{tabular}

Lsd: Azot: 3.8I4, Lsd Sivı atık: 2.826, Lsd Azot x Sivı: 4.895

Azot ve Sıvı atık dozlarına ait genel ortalamalar büyük harf ile gösterilmiștir. 
incelendiğinde, denemede en yüksek bayrak yaprak alan miktarı $35.64 \mathrm{~cm} 2$ ile $18 \mathrm{~kg} / \mathrm{da}$ mineral azot ile $2 \mathrm{t} / \mathrm{da} \mathrm{sıvı}$ biyogaz uygulamasından elde edilmiștir. En düșük değer olan $18.83 \mathrm{~cm} 2$ bayrak yaprak alan miktarı ise $0 \mathrm{~kg} / \mathrm{da}$ mineral azot ile $0 \mathrm{t} / \mathrm{da}$ sıvı biyogaz atık uygulamasında ölçülmüștür. Elde edilen sonuçlara göre mineral azot dozu ve sıvı biyogaz atık uygulamalarının bayrak yaprak alan miktarları üzerine önemli etkileri olduğu saptanmıștır. Ancak bu parametrede mineral azot dozunun etkisi sıvı biyogaz atık dozuna göre çok daha belirgin olmuștur. En yüksek değerler en yüksek mineral azot uygulamaları ile birlikte I ve 2 ton/da sıvı biyogaz atık uygulamalarında ulașılırken $9 \mathrm{~kg} / \mathrm{da}$ mineral azot uygulamasının 3 ve 4 ton/da uygulamalarında da kayda değer yaprak alan miktarlarına ulașıldığı görülmektedir.
Artan bayrak yaprak alanları ile bașak fotosentezinin buğday veriminde önemli rol oynadığı, kılçıklı ve dar yapraklı çeșitlerin verime katkılarının kılçıksız çeșitlere oranla daha yüksek olduğu belirtilmiștir (Ünay ve ark., 2005).

\section{Hektolitre Ağırlığı}

Hektolitre ağırlığına ilișkin varyans analiz sonuçlarına göre mineral azot gübre dozu istatistiksel açıdan önemsiz bulunurken, sıvı biyogaz atık uygulaması ve mineral azot $\mathbf{x}$ sıvı biyogaz interaksiyonu istatistiksel açıdan 0.0 I seviyesinde önemli bulunmuștur.

Yapılan çalıșmada tane hektolitre ağırlı̆̆ bakımından uygulamalar arası farklııılar ve ortalama değerler Çizelge 6'da verilmiștir. Hektolitre ağırlıkları 79.06 kg/hl ile 84.10

Çizelge 6. Hektolitre ağırlığına ilișkin ortalama değerler $(\mathrm{kg} / \mathrm{hl})$

\begin{tabular}{lllll}
\hline Azot/Sıvı & $\mathbf{0 ~ k g / d a}$ & $\mathbf{9 ~ k g / d a}$ & $\mathbf{I 8 ~ k g / d a}$ & Ortalama \\
\hline $0 \mathrm{t} / \mathrm{da}$ & $82.33 \mathrm{cde}$ & $82.86 \mathrm{bcd}$ & $82.17 \mathrm{de}$ & $82.45 \mathrm{C}$ \\
$1 \mathrm{t} / \mathrm{da}$ & $83.36 \mathrm{~b}$ & $82.90 \mathrm{bc}$ & $82.47 \mathrm{cde}$ & $82.91 \mathrm{~B}$ \\
$2 \mathrm{t} / \mathrm{da}$ & $82.43 \mathrm{cde}$ & $79.06 \mathrm{~g}$ & $81.06 \mathrm{f}$ & $80.85 \mathrm{E}$ \\
$3 \mathrm{t} / \mathrm{da}$ & $84.10 \mathrm{a}$ & $82.98 \mathrm{bc}$ & $82.89 \mathrm{bc}$ & $83.32 \mathrm{~A}$ \\
$4 \mathrm{t} / \mathrm{da}$ & $81.78 \mathrm{e}$ & $82.48 \mathrm{~cd}$ & $80.80 \mathrm{f}$ & $81.68 \mathrm{D}$ \\
Ortalama & 82.80 & 82.05 & 81.88 & \\
\hline
\end{tabular}

Lsd: Azot: öd, Lsd Sıvı atık: 0.398, Lsd Azot x Sıvı: 0.690

Azot ve Sıvı atık dozlarına ait genel ortalamalar büyük harf ile gösterilmiștir.

kg/hl arasında değișim göstermiștir. Mineral azot dozu uygulamalarının etkileri önemsiz bulunurken sıvı biyogaz dozu hektolitre ağırlıklarının önemli oranda değișmesine neden olmuștur. En düșük hektolitre ağırlığı $9 \mathrm{~kg} / \mathrm{da}$ azot dozu ile 2 t/da sıvı biyogaz atık uygulamasında elde edilirken en yüksek hektolitre ağırlığı ise $0 \mathrm{~kg} / \mathrm{da}$ mineral azot dozu ile $3 \mathrm{t} / \mathrm{da}$ sıvı atık uygulamasında saptanmıștır.

Hektolitre ağırlığı dane iriliği ve dane homojenliği ile ilgili bir parametredir ve bazı durumlarda düșük verimlerde dahi yüksek hektolitre ağırlıklarına ulașılabilmektedir (Erekul, 2000). Çalıșmada daha düșük mineral azot ve sıvı biyogaz atığı uygulamalarında genel olarak daha yüksek ortalama hektolitre ağırlıklarına ulașılmıștır. Șengün (2006) Aydın ilinde ekmeklik buğday çeșitlerinde yaptığı bir çalıșmada farklı buğday çeșitlerinde hektolitre ağırlığını $78.3 \mathrm{~kg} / \mathrm{hl}$ ile $86.0 \mathrm{~kg} / \mathrm{hl}$ arasında değiștiğini bildirmiștir.

\section{Bin Tane Ağırlığı (gr)}

Bin tane ağırlığına ilișkin varyans analiz sonuçlarına göre mineral azotlu gübreleme, sıvı biyogaz atık uygulaması ve mineral azot $x$ sıvı biyogaz atık interaksiyonu istatistiksel açıdan 0.01 seviyesinde önemli bulunmuștur.

Bin tane ağırlığı değerleri $36.94 \mathrm{~g}$ ile $58.83 \mathrm{~g}$ arasında önemli farklar gösterdiği saptanmıștır. Çalıșmada elde edilen en önemli sonuçlardan biri mineral azot uygulamasının olmadığı sıvı biyogaz atığı uygulamalarında en yüksek bin tane ağırlıklarına ulașılmıș olmasıdır. En yüksek bin tane ağırlığı mineral azotun uygulanmadığı 4 ton/da sıvı biyogaz atığının uygulandığı parsellerden elde edilmiștir. En düșük değer ise hiçbir gübrenin uygulanmadığı parsellerde saptanmıștır. Artan mineral azot dozu uygulamalarının bin tane ağırlığının azalmasına neden olduğu görülmüștür. Mineral azot ile sıvı biyogaz atığı interaksiyonunun bin tane ağırlığı üzerinde belirgin bir etkisi olmamıștır (Çizelge 7).

Çizelge 7. Bin tane ağırlığına ilișkin ortalama değerler $(\mathrm{kg} / \mathrm{hl})$

\begin{tabular}{lllll}
\hline Azot/Sıvı & $\mathbf{0 ~ k g / d a}$ & $\mathbf{9} \mathbf{~ k g / d a}$ & $\mathbf{I 8 ~} \mathbf{~ k g / d a}$ & Ortalama \\
\hline $0 \mathrm{t} / \mathrm{da}$ & $36.94 \mathrm{~h}$ & $46.33 \mathrm{de}$ & $41.90 \mathrm{gh}$ & $41.72 \mathrm{C}$ \\
$\mathrm{I} \mathrm{t/da}$ & $48.39 \mathrm{bcd}$ & $44.80 \mathrm{ef}$ & $43.00 \mathrm{fg}$ & $45.39 \mathrm{~B}$ \\
$2 \mathrm{t} / \mathrm{da}$ & $47.00 \mathrm{cde}$ & $46.03 \mathrm{de}$ & $42.70 \mathrm{fg}$ & $45.24 \mathrm{~B}$ \\
$3 \mathrm{t} / \mathrm{da}$ & $50.17 \mathrm{~b}$ & $42.06 \mathrm{gh}$ & $43.26 \mathrm{fg}$ & $45.17 \mathrm{~B}$ \\
$4 \mathrm{t} / \mathrm{da}$ & $58.83 \mathrm{a}$ & $46.34 \mathrm{de}$ & $49.70 \mathrm{bc}$ & $51.62 \mathrm{~A}$ \\
Ortalama & $48.26 \mathrm{~A}$ & $45.1 \mathrm{I} \mathrm{B}$ & $44.1 \mathrm{I} \mathrm{B}$ & \\
\hline
\end{tabular}

Lsd: Azot: I.049, Lsd Sivı atık: I.560, Lsd Azot x Sıvı: 2.703

Azot ve Sıvı atık dozlarına ait genel ortalamalar büyük harf ile gösterilmiștir. 
Bin tane ağırlığı tahıllarda verimi etkileyen önemli verim öğelerinden biridir. Tane dolum döneminin yani çiçeklenme ile sarı olum dönemi arasındaki sürenin uzun olması ve bu süre içerisinde tanenin yeterli düzeyde beslenebilmesi bin tane ağırlığının artmasına olumlu etkide bulunur (Baysal, 20।4). Çöl (2007), buğdayda temel gübrelemenin yanında çiçeklenme döneminde yapılan mineral azotlu gübrelemenin bin tane ağırlığını arttırdığını saptamıștır. Farklı organik gübre formlarının özellikle mineral azotun uygulanmadığı parsellerde bin tane ağırlığı üzerinde olumlu etkiler saptanmıștır (Asmus ve ark., 1987).

\section{Tane Verimi (kg/da)}

Tane verimine ilișkin varyans analiz sonuçları incelendiğinde mineral azot dozu ve sivı biyogaz atık dozunun 0.01 seviyesinde önemli bulunmuștur, mineral azot $x$ sıvı biyogaz atığı interaksiyonu ise 0.05 seviyesinde önemli bulunmuștur. Farklı azot ve sıvı biyogaz atık dozlarına ilișkin tane verimi değerleri Çizelge 8'de verilmiștir. Ortalama tane verimlerinin $194.9 \mathrm{~kg} / \mathrm{da}$ ile $466.0 \mathrm{~kg} / \mathrm{da}$ arasında değiștiği görülmektedir. En düșük tane verimi $0 \mathrm{~kg} / \mathrm{da}$ mineral azot ile $0 \mathrm{t} / \mathrm{da}$ sivı biyogaz atık uygulamasindan elde edilirken en yüksek tane verimi $18 \mathrm{~kg} / \mathrm{da}$ mineral azot ile 3 ton/da sivı

Çizelge 8. Tane verimine ilișkin ortalama değerler $(\mathrm{kg} / \mathrm{da})$

\begin{tabular}{lllll}
\hline Azot/Sıvı & $\mathbf{0 ~ k g / d a}$ & $\mathbf{9 ~ k g / d a}$ & $\mathbf{1 8} \mathbf{~ k g / d a}$ & Ortalama \\
\hline $0 \mathrm{t} / \mathrm{da}$ & $194.93 \mathrm{~d}$ & $292.49 \mathrm{c}$ & $438.29 \mathrm{ab}$ & $308.57 \mathrm{C}$ \\
$\mathrm{I} \mathrm{t} / \mathrm{da}$ & $201.69 \mathrm{~d}$ & $305.15 \mathrm{c}$ & $426.67 \mathrm{ab}$ & $311.17 \mathrm{C}$ \\
$2 \mathrm{t} / \mathrm{da}$ & $315.91 \mathrm{c}$ & $319.73 \mathrm{c}$ & $418.33 \mathrm{ab}$ & $351.32 \mathrm{BC}$ \\
$3 \mathrm{t} / \mathrm{da}$ & $414.91 \mathrm{ab}$ & $353.51 \mathrm{bc}$ & $466.01 \mathrm{a}$ & $411.48 \mathrm{~A}$ \\
$4 \mathrm{t} / \mathrm{da}$ & $328.67 \mathrm{c}$ & $313.04 \mathrm{c}$ & $455.76 \mathrm{ab}$ & $365.82 \mathrm{AB}$ \\
Ortalama & $291.67 \mathrm{C}$ & $316.78 \mathrm{~B}$ & $441.01 \mathrm{~A}$ & \\
\hline
\end{tabular}

Lsd: Azot: 2I.369, Lsd Sivı atık: 49.654, Lsd Azot x Sivı: 86.004

Azot ve Sıvı atık dozlarına ait genel ortalamalar büyük harf ile gösterilmiștir.

biyogaz atığı uygulamasından elde edilmiștir. Mineral azot ve sıvı biyogaz kombinasyonu tane veriminin önemli düzeyde artmasına neden olmuștur. En yüksek verimlerin olușması için en yüksek düzeyde mineral azot dozuna ihtiyaç duyulmuștur. Dikkate değer sonuçlardan biri ise $18 \mathrm{~kg} / \mathrm{da}$ mineral azot dozu ile elde edilen tane verimi ile sadece 3 ton/da sıvı biyogaz atığı uygulamasından elde edilen tane verimin istatistiki olarak aynı grupta yer almaları ve böylece istatistiki olarak bir farkın bulunmamasıdır.

\section{Tanede Protein Oranı}

Protein oranına ilișkin varyans analizi verilerinde mineral azot dozları ve sıvı biyogaz atık uygulaması istatistiksel açıdan önemsiz bulunurken, mineral azot dozu $x$ sıvı biyogaz atık interaksiyonu ise 0.01 seviyesinde önemli bulunmuștur.

Denemede farklı mineral azot dozu ve farklı biyogaz atığ uygulamaları ile kombinasyonları buğday bitkisinde protein oranların \%।3.33 ile \%।4.93 arasında değișmesine neden olmuștur (Çizelge 9.). Mineral azot dozlarının artması protein oranlarında herhangi bir değișime neden olmamıștır. Aynı șekilde biyogaz atığı dozlarının artması da protein oranlarında önemli bir değișim meydana getirmemiștir. Düșük mineral azot ve biyogaz atığı dozlarında protein oranların biraz daha yüksek çıkması bu dozlarda daha düșük olan tane verimleri ile açıklanabilir (Erekul ve ark., 2009). Ancak genel olarak protein ortalamaları yeterli bir seviyede bulunmuștur.

Ekmeklik buğday kalitesi için undaki protein içeriği önemli bir kalite kriteridir. Buğday tanesinde mineral azot ve farklı organik gübre formlarının daha önce yapılan çalıșmalarda da tane protein miktarı üzerine olumlu etkisinin olduğu belirtilmiștir Erekul, 2000; Bozkurt ve ark., 2000; Erekul ve ark., 2009).

Çizelge 9. Tanede toplam protein oranına ilișkin ortalama değerler (\%)

\begin{tabular}{|c|c|c|c|c|}
\hline Azot/Sıvı & $0 \mathrm{~kg} / \mathrm{da}$ & $9 \mathrm{~kg} / \mathrm{da}$ & $18 \mathrm{~kg} / \mathrm{da}$ & Ortalama \\
\hline $0 \mathrm{t} / \mathrm{da}$ & $14.93 \mathrm{a}$ & $14.23 \mathrm{abcd}$ & 14.12 bcd & 14.12 \\
\hline $\mathrm{l} t / \mathrm{da}$ & $14.25 \mathrm{abcd}$ & I4.42 abc & $14.50 \mathrm{abc}$ & 14.39 \\
\hline $2 \mathrm{t} / \mathrm{da}$ & $14.33 \mathrm{abcd}$ & $14.18 \mathrm{bcd}$ & $13.33 \mathrm{e}$ & 13.94 \\
\hline $3 \mathrm{t} / \mathrm{da}$ & $13.69 \mathrm{de}$ & $14.59 \mathrm{ab}$ & $14.23 \mathrm{abcd}$ & 14.17 \\
\hline $4 \mathrm{t} / \mathrm{da}$ & I3.82 cde & $14.58 \mathrm{ab}$ & $14.32 \mathrm{abcd}$ & 14.24 \\
\hline Ortalama & 14.20 & 14.40 & 14.10 & \\
\hline
\end{tabular}

Lsd: Azot: öd, Lsd Sıvı atık: öd, Lsd Azot x Sıvı: 0.7।8

Azot ve Sıvı atık dozlarına ait genel ortalamalar büyük harf ile gösterilmiștir.

\section{Toplam Antioksidan Aktivite (\%inhibisyon)}

Günlük beslenmede önemli yeri olan buğdayın sağlık açısından da katkıları bulunmaktadır. Özellikle sebzelerin sağlık açısından önemli olduğu ancak sebzelerin antioksidan içeriğinin sınırlı kalabileceği ve bazı kahvaltılık tahılların 
önemli düzeyde antioksidan içeriğine sahip olduğu bildirilmiștir (Miller ve ark., 2000).

Ekmeklik buğday tanesinde toplan antioksidan aktivite değerlerine ilișkin ortalama değerler Çizelge 10'da verilmiștir. Elde edilen değerler incelendiğinde interaksiyon önemli bulunmuș ancak azot dozu ve sıvı dozların ortalama değerleri arasında herhangi bir fark tespit edilememiștir.

Çizelge I0. Tanede toplam antioksidan aktivitesine ilișkin ortalama değerler (\%)

\begin{tabular}{lllll}
\hline Azot/Sıvı & $\mathbf{0 ~ k g / d a}$ & $\mathbf{9 ~ k g / d a}$ & $\mathbf{I 8 ~} \mathbf{~ g g / d a}$ & Ortalama \\
\hline $0 \mathrm{t} / \mathrm{da}$ & $15.909 \mathrm{a}$ & $11.544 \mathrm{~b}$ & $16.667 \mathrm{a}$ & 14.707 \\
$1 \mathrm{t} / \mathrm{da}$ & $15.733 \mathrm{a}$ & $15.476 \mathrm{a}$ & $14.971 \mathrm{a}$ & 15.394 \\
$2 \mathrm{t} / \mathrm{da}$ & $15.837 \mathrm{a}$ & $15.621 \mathrm{a}$ & $16.125 \mathrm{a}$ & 15.861 \\
$3 \mathrm{t} / \mathrm{da}$ & $16.414 \mathrm{a}$ & $15.645 \mathrm{a}$ & $15.115 \mathrm{a}$ & 15.825 \\
$4 \mathrm{t} / \mathrm{da}$ & $14.394 \mathrm{a}$ & $14.178 \mathrm{ab}$ & $16.667 \mathrm{a}$ & 15.079 \\
Ortalama & 15.657 & 14.553 & 15.909 & \\
\hline
\end{tabular}

Lsd: Azot: öd, Lsd Sıvı atık: öd, Lsd Azot x Sıvı: 2.642

Azot ve Sıvı atık dozlarına ait genel ortalamalar büyük harf ile gösterilmiștir.

Ortalama değerler incelendiğinde antioksidan aktivite özelliğinin ortalamalar arasında fark yaratmaması bu özelliğin çeșit özelliğine bağlı olarak daha çok değiștiğini göstermektedir. Konu ile ilgili yapılan önceki çalıșmalarda çeșitler arası önemli farklılıkların bulunduğunu ortaya koymuștur (Adom ve ark., 2003; Mpofu ve ark., 2006). Gübre uygulamalarında en yüksek değer $18 \mathrm{~kg} / \mathrm{da}$ azot dozunda \%।5.909 değeri ile elde edilirken, sıvı biyogaz atığı dozu olarak 3 ton/da uygulamasından en yüksek değer elde edilmiștir (Çizelge 10). Antioksidan aktivite bakımından interaksiyon incelendiğinde $18 \mathrm{~kg} / \mathrm{da}$ azot ile 0 ve $4 \mathrm{ton} / \mathrm{da}$ sıvı biyogaz atığı dozlarının kombinasyonundan daha yüksek değerler elde edilmiștir.

\section{SONUÇ}

Araștırmada; mineral azot gübresinin yanında bölgede ve buğday kültür bitkisinde ilk kez tarla koșullarında denenen biyogaz atığının buğdayın tane verimi ve tane kalitesi üzerine olumlu bir etkisinin olduğu sonucuna varılmıștır. Söz konusu sıvı biyogaz atığının bitkisel üretim sistemlerinde verimin ve kalitenin arttırılmasında ve toprak verimliliğinin korunmasında ve geliștirmesinde alternatif bir organik gübre olarak kullanılabileceği görülmüștür. Özellikle ülkemizde ki toprakların sürekli azalma eğilimi içerisine giren organik maddenin arttırılmasında ve ağırlıklı olarak mineral gübrelere dayalı tarım sistemlerinde mineral gübrelerin olumsuz etkilerinin azaltılmasında ve tasarrufunda yarar sağlayabileceği sonucuna da varılmıștır. Ancak organik gübrelerin verim ve kalite üzerine etkilerinin uzun süreli (yıllar) uygulamalar sonrasında etkisinin ortaya çıkacağı düșüncesiyle mevcut çalıșmalara çok yönlü olarak devam edilmesi gerektiği sonucuna varılmıștır.

\section{TEȘEKKÜR}

$\mathrm{Bu}$ çalıșma kapsamında Adnan Menderes Üniversitesi Bilimsel Araștırma Projeleri Birimine ZRF-I7019 no'lu proje kapsamında yaptıkları desteklerden dolayı teșekkür ederiz.

\section{KAYNAKLAR}

Adom KK, Sarrells ME, Liu RH (2003) Phytochemical Profiles and Antioxidant Activity of Wheat Varieties. J. Agric. Food Chemistry 5I: 7825-7834.
Allesi J, Power F (1973) Effect of Source and Rate N Uptake and Fertilizer Efficiency by Spring Wheat and Barley. Agronomy Journal 65: 53-55.

Anonim (2012) Toprak Mahsülleri Ofisi, 2012 Hububat Sektör Raporu.

www.tmo.gov.tr Erișim Tarihi: 12.10.2017.

Asmus F, Kittelmann G, Görlitz, H (1987) Einflusslang jähriger organischer Düngung auf physikalische Eigen schaften einer Tieflehm-Fahlerde. Arch. Acker-Pfl. Boden 3I: 4I-46.

Asmus F, Görlitz H, Blüttchen, G (1990) Ergebnisseauseinem 30 Einfluss langjährigen

Dauerversuchzu Fragen der organischen Düngungauf Tieflehm- Fahlerde in Gross-Kreutz. Arch. AckerPfl. Boden 34: 4l-46.

Baysal Z (2014) Aydın Ekolojik Koșullarında Çinko Uygulamasının Buğday'ın (Triticum aestivum L.) Tane Verimi ve Kalitesi Üzerinde Etkisi. Adnan Menderes Üniversitesi Fen Bilimleri Enstitüsü, 59, Aydın.

Bozkurt MA, Yılmaz İ, Çimrin KM (2000) Kentsel Arıtma Çamurunun Kıșlık Arpada Azot Kaynağı Olarak Kullanılması. Ankara Üniversitesi Ziraat Fakültesi Tarım Bilimleri Dergisi,7(I): I05-I I0.

Brand Williams W, Cuvelier ME, Berset C (1995) Use of a Radical Method to Evaluate Antioxidant Activity. Lebensm. Wiss. U. Technology Food Science and Technology 28 (I): 25-30.

Çevik A (2016) Çanakkale İli'ndeki Hayvansal Atıkların Biyogaz Potansiyelinin Değerlendirilmesi. Çanakkale Onsekiz Mart Üniversitesi Sosyal Bilimler Enstitüsü, 78, Çanakkale.

Çöl M (2007) Geçmișten Günümüze Ekmeklik Buğdayda Verim ve Kalitedeki Gelișmeler. Selçuk Üniversitesi Fen Bilimleri Enstitüsü Tarla Bitkileri Ana Bilim Dalı, 68 , Konya.

Değirmenci G (20I7) Bazı Makarnalık Buğday (Triticum durum L.) Çeșitlerinin Verim, Kalite ve Antioksidan Aktivite Özelliklerinin Belirlenmesi. Adnan Menderes Üniversitesi Fen Bilimleri Enstitüsü Tarla Bitkileri Ana Bilim Dalı, 44, Aydın.

Doğan $Y$ ve Kendal E (20I2) Ekmeklik buğday (Triticum aestivum L.) Genotiplerinin Tane Verimi ve Bazı Kalite 
Özelliklerinin Belirlenmesi. GOÜ Ziraat Fakültesi Dergisi, 29(I): I|3-|2|.

Entr JA, Wood BH, Edwards JH, Wood CW (1997) Influence of Organic By- Products and Nitrogen Source on Chemical and Microbiological Status of an Agricultural Soil. Biol. Fertil. Soil 24:196-204.

Erekul O (2000) Einflusslangjährig differenzierter Düngungauf Ertrag und Qualitaet von Winter weizen und Sommergerste. Standortvergleich Berlin (D) Tartu(EST). CuvillierVerlag, Göttingen, I57s.

Erekul O, Kautz T, Ellmer F, Turgut, İ (2009) Yield and Bread-making Quality of Different Wheat (Triticum aestivum L.) Genotypes Grown in Western Turkey. Archives of Agronomy and Soil Science 55: 162-168.

FAO (2016) Dünya Tarım ve Gıda Örgütü (FAO) İstatistikleri. www.fao.org Erișim Tarihi:10.02.2018.

Göçmez S (2006) Menemen Ovası Topraklarında İzsu Kentsel Arıtma Çamur Uygulamalarının Mikrobiyal Aktivite ve Biyomass ile Bazı Fiziksel ve Kimyasal Toprak Özellikleri Üzerine Etkisi. Ege Üniversitesi Fen Bilimleri Enstitüsü Toprak Ana Bilim Dalı, 224, İzmir.

Gümüș I, Șeker C (20I4) Farklı Organik Gübrelerin MısırBuğday Ekim Nöbetinde Buğdayın Verimine Bakiye Etkileri. Toprak Su Dergisi, 3(I):I-5.

Gürel A (20I2) Humus Biyogaz Döngüsü ve Biyogaz Atıklarının Humus Etkisi. SAÜ Fen Edebiyat Dergisi I: 363-37I.

Hay RK, Walker AJ (1989) An Introduction to the Physiology of the Crop Yield. Logmansci. Andtech., New York.

Kara B, Gül H (20I3) Alternatif Gübrelerin Farklı Ekmeklik Buğday Çeșitlerinin Tane Verimi, Verim Komponentleri ve Kalite Özelliklerine Etkileri. Süleyman Demirel Üniversitesi Ziraat Fakültesi Dergisi 8(2):88-97

Koca A (20II) İklim Değișikliklerinin Tarıma Etkisi. International Trade Forum. www.hububatbirlik.org Erișim Tarihi: 15.11.2017

Koca A (2007) Yenilenebilir Bir Enerji Kaynağı Biyogaz. Doğu Anadolu Bölgesi Araștırma Dergisi 5(3): 32-35.
Kim MC, Song JY, Hwang KJ, Song ST, Hyun CH, Kang TH (2008) The Effects of Application of Liquid Swine Manure on Productivity of Rye and Subsequent Soil Quality. Journal of the Korean Society of Grassland and Forage Science 2I: 8I-88.

Kılıç ÇF (20II) Biyogaz, Önemi, Genel Durumu ve Türkiye'de ki Yeri. Mühendis ve Makine 52(6I7): 94106.

Lloveras J, Lopez A, Ferran J, Espachs S, Solsona J (200I) Bread-making Wheat and Soil Nitrate as Affected by Nitrogen Fertilization in Irrigated Mediterranean conditions. Agronomy Journal 93:1 I83-1 I 90.

Miller HE, Rigelhof F, Marquart L, Prokash A, Kanter M (2000) Antioxidant Content of Whole Grain Breakfast Cereals, Fruits and Vegetables. Journal of the American College of Nutrition 19 (3): 312-319.

Mpofu A, Sopirstein HD, Beta T (2006) Genotype and Environmental Variation in Phenolic Content, Phenolic Acid Composition and Antioxidant Activity of Hard Spring Wheat. J. Agric. Food Chemistry 54:1265-1270.

Ramussen PE, Rohde CR (1988) Stubble Burning Effects on Winter Wheat Yield and Nitrogen Utilization Under Semi Arid Conditions. Agronomy Journal 80(6): 940942.

Șehirali S, Gençtan T, Birsin MA, Zencirci N, Uçkesen B (2000). Türkiye Tahıl ve Yemeklik Tane Baklagil Üretiminin Bugünkü ve Gelecekteki Boyutları. V. Ziraat Mühendisliği Teknik Kongresi, s: 43I-452, Ankara.

Șeker C, Karakaplan S (1999) Konya Ovasinda Toprak Özellikleri ile Kırılma Değerleri Arasındaki İlișkiler. Tr. J. of Agriculture and Forestry 29: 183-190.

Șengün B (2006) Ekmeklik Buğday Yeni Islah Hatlarında Bazı Agronomik ve Kalite Özellikleri. Adnan Menderes Üniversitesi Ziraat Fakültesi Tarla Bitkileri Bölümü Yüksek Lisans Tezi, Aydın.

Ünay A, Konak C, Sezener V, Çağııııı N (2005) Buğday'da (Triticum aestivum L. em Thell) Bayrak Yaprağı Özelliklerinin Kalııımı ve Verim ile İlișkileri. ADÜ Ziraat Fakültesi Dergisi 2(I): 23-27. 